(昭和 45 年 12 月 21 日 受理)

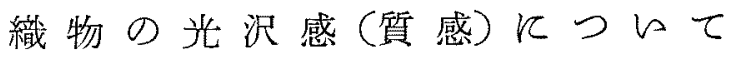

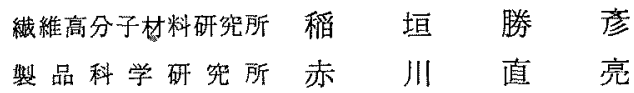

\title{
INFLUENCES OF TEXTURE ON THE FABRIC LUSTER (QUALITY)
}

By Katsuhiko Inagaki* and Naosuke Akagawa**

*(Research Institute for Polymers and Textiles, Kanagawa-ku, Yokohama, Japan) **(Industrial Products Research Institute, Ōta-ku, Tokyo Japan)

In the previous paper, the quality of luster of fabrics was discussed from the standpoint of a heap film.

In this paper, it is discussed mainly the influences of texture on the fabric luster (quality).

The results obtained are as follows:

1. The luster (quality) of textured surface is equal to that of the plane excluding the texture of fabric, when the size of textures is larger than the analytical ability of human eyes, while, when the size is beyond the abitity, it is determined by $\Sigma$ (reflecting distribution of texture).

2. In fabrics, the parallel property of fiber affects the fabric luster. This is caused by the change of directional properties of reflecting elements at the boundary of fiber and air relating with parallel property of fiber.

3. The relation between the luster of satain weave and of heap films which is asumed to have a plane excluding the texture of fabric becomes clear in this study.

The quality of luster is expressed on the same coodinate system as that of plane materials.

(Received December 21, 1970)

\section{1.は じめ に}

織物の光沢感を表現する言蓧は。第 1 表のように分類 できると若える。これらのうち，1，2，3，5 群の表現 壮質感の，第 4 群は，量感の評洒であるが，5群は，価 值評洒に近いるので，他の丧現とは異質のるのと考党ら れる。第 2 表は，織物の光沢感を他の物体との風係から モデル的に位置づけたものであるが，第 1 表，第 2 表を

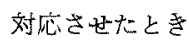

第 1 群; 織物面からテクスキャー（織目）を取り去っ た平面の光沢感として評便したもの。

第 2 群; テクスチャーの光っている部分と暗い部分と のコントラストに重点を置いた諳洒。

第 3 群；反射光が表面かららでているのか，内部から出 ているのかとい5ような，反射光の出所敒関係した評 侢。と考学ることができる。

ここから，織物光沢の質感の評洒を，次の 3 つの問題 に集約して考党た。

1. 織物面からテクスチャーを取り去った平面は何
か。また，午の平面により，金属状，真珠状，ろう状な どの光沢感を演出できる。

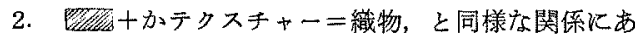
る全属板の光沢感は, テクスチャーの存在によりどのよ 5 に変化するか。

3. 織物と同様な反射機棈を持つ平面である既局の反 射成分はよ゙のような性質を持ら，光沢感にとのような影 響を与えているか。

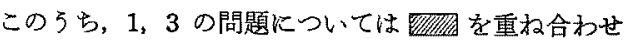
フィルムと蛒いてすで考察した ${ }^{1,2)}$ 。本報告では，2 の關題を中心に検討し，先の倹討結果之の対応加ら，織 物光沢の質感の評価について考光た。

\section{2. 㹡散反射光と目の分解能}

\section{1 鋼球銅棒を並べた平面についての官能検査}

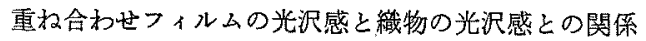
は、テクステャ一の形状，大きさなどによって定まるる のと考えられるが，先にも述へたようにこの関係は， 金属板と金属梨地面の光沢感との関你と全く同一である 
Table 1. Classification the expession of fabric luster

\begin{tabular}{l|l|l}
\hline $\begin{array}{l}\text { Expression representing the } \\
\text { luster of other material }\end{array}$ & $\begin{array}{l}\text { 3. } \begin{array}{l}\text { Expression concerned with } \\
\text { the source of reflection }\end{array} \\
\text { Metal like, Waxy }\end{array}$ & $\begin{array}{l}\text { Surficial luster, } \\
\text { (uwabikari) } \\
\text { Matte luster, } \\
\text { (ibushita tsuya) }\end{array}$ \\
\hline Pearl like, Milky, Dull bikari) \\
\hline \begin{tabular}{l|l|l} 
Expression concerned with \\
texture of fabric
\end{tabular} & $\begin{array}{l}\text { 4. Quantity of } \\
\text { luster }\end{array}$ & 5. etc. \\
\hline $\begin{array}{l}\text { Frostysparkle, Rich high light, } \\
\text { Lively look, shiny look }\end{array}$ & $\begin{array}{l}\text { Lustrous } \\
\text { Poor luster } \\
\text { Non luster }\end{array}$ & $\begin{array}{l}\text { Expensive look } \\
\text { Elegant luster } \\
\text { Showy luster }\end{array}$ \\
\hline
\end{tabular}

じられなくなるのに対し，锥測条件 Iでは，棒の太さが目の分解能（視 角）以下となっても光沢感が感じら れる。また，同時に行なった質問 「光沢感が感じられる䠄囲では, こ れらの面はとの上ら炎光沢感を示す か」汇対し，すべての被駼者が，鋼 球は鋼板と同質の銅柈は銅板之同質 の光沢感が感じられると答克てい る。第 3 图《は，各々の試料の拡散 反射曲線老示したが，鋼球，銅棒の 条件 IIの測定では反射光分有が搪散

Table 2. Positioning the fabric luster

METAL PLATE + TEXTURE $=$ METAL TEXTURED
GLASS PLATE + TEXTURE $=$ FRACE
FITIMIMIIV + TEXTURE $=$ DIAMOND GLASS
FABRIC

ものと考壳られる。金属の場合には，物質が定まれば， 平板状態での光沢感は，重狈合わせフィルムの場合の上 5に，他の要素により左右されることなく一義的に定ま る。したがって、テクスチャーによる影響を検討する上 には，他の要素が入り込まない金属面について実験する のがよいとの観点から次の実験を行なった。

第1図に示す上万な観測条件を設定し，鋼球，銅棒を 並べた平面を，光源に対し $45^{\circ}$ 㑯けて置き，これを微澌 したとき，鋼球，銅棒をそれぞれ認知できる限界距㒕， これらの面に光沢感が感しられる限界距離，コントラス トさえ感じられくなる限界距離起各被験者に示させ,

その平均值により議論した。

被験者には，当所穖物関係者の5 万視力 1.0 以上の 10 人を用いた。試料, 钼湘条件, 結果は, 第 3 表, 第 4 表 に示したと拈りである。第5 表は，図形の大きさと目の 分解能との関係についての横瀨の結果を示しだ)。第 3 表〜第 5 表を対応させたとき，鋼球，銅棒いつれの場合 も，物体の認知ができなくなる限界(視奥)，コントラス トさ光感じられなくなる限界は，図形の形態認知，存在 諗知の限界 (視角) にほぼ一致している。これは，反射 物体についても，図形の認知についての結果が十分適用 できること京示して拈り，また，光沢感の認知について の官能検查結果の信頼性をむ示しているるのと考えられ る。

官能検査の結果によれば，テクスチャーが球面をなし ている場合，球の大きさが目の分解能（視角）以下とな れば，全く光沢感を感じることができず，銅棒の場合も 第 2 図観湘条件 IIでは，銅球と同様な時点で光沢感が感

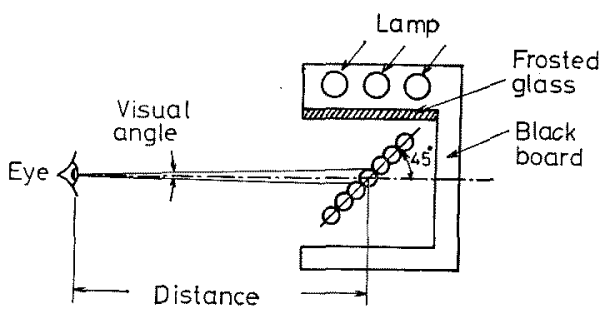

Fig. 1. Observed condition.

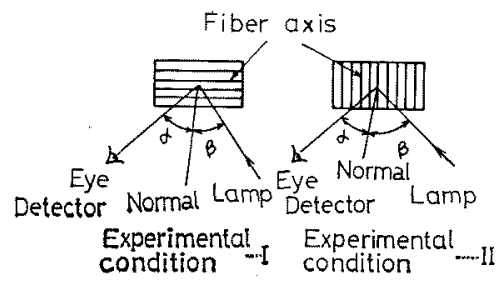

Fig. 2. Direction of observation.

Table 3. Results of visual test

\begin{tabular}{c|c|c|c}
\hline & $\begin{array}{c}\text { Limit of } \\
\text { recognition } \\
\text { of existance }\end{array}$ & $\begin{array}{c}\text { Limit of } \\
\text { recognition } \\
\text { of luster }\end{array}$ & $\begin{array}{c}\text { Limit of } \\
\text { recognition } \\
\text { of shape }\end{array}$ \\
\hline A & $26.1 \mathrm{~m}$ & $21.0 \mathrm{~m}$ & $12.2 \mathrm{~m}$ \\
B & 23.7 & 20.7 & 10.2 \\
D & 21.3 & 16.3 & 8.0 \\
E & 22.1 & 17.5 & 9.0 \\
F & 22.3 & 18.6 & 9.0 \\
G & 23.2 & 23.3 & 12.8 \\
H & 23.1 & 20.2 & 10.0 \\
I & 23.0 & 19.5 & 9.6 \\
J & 25.1 & 20.8 & 9.0 \\
\hline Mean & 23.9 & 19.7 & 10.1 \\
\hline Visual angle & $1.44^{\prime}$ & $1.75^{\prime}$ & $3.41^{\prime}$ \\
\hline Steel ball ; dia. $10 \mathrm{~mm}$ contrast ratio of light \\
and shade 8.0 & &
\end{tabular}


Table 4. Result of visual test

\begin{tabular}{|c|c|c|c|c|c|c|}
\hline & \multirow{2}{*}{\multicolumn{2}{|c|}{$\begin{array}{c}\text { Limit of recogni- } \\
\text { tion of existance } \\
\text { Experimental } \\
\text { condition }\end{array}$}} & \multirow{2}{*}{\multicolumn{2}{|c|}{$\begin{array}{l}\text { Limit of recogni- } \\
\text { tion of luster } \\
\begin{array}{c}\text { Experimental } \\
\text { condition }\end{array}\end{array}$}} & \multirow{2}{*}{\multicolumn{2}{|c|}{$\begin{array}{c}\text { Limit of recogni- } \\
\text { tion of shape } \\
\text { Experimental } \\
\text { condition }\end{array}$}} \\
\hline & & & & & & \\
\hline & I & III & I & II & I & II \\
\hline$A^{\prime}$ & $22.5 \mathrm{~m}$ & $19.0 \mathrm{~m}$ & - & $14.0 \mathrm{~m}$ & $6.1 \mathrm{~m}$ & $5.5 \mathrm{~m}$ \\
\hline$B^{\prime}$ & 22.3 & 18.0 & - & 15.0 & 6.6 & 5.6 \\
\hline $\mathrm{C}^{\prime}$ & 23.0 & 16.5 & - & 16.3 & 6.6 & 5.1 \\
\hline $\mathrm{D}^{\prime}$ & 22.1 & 19.5 & - & 14.0 & 10.1 & 6.4 \\
\hline$E^{\prime}$ & 21.8 & 20.6 & - & 13. 6 & 7.7 & 5.1 \\
\hline$F^{\prime}$ & 24.4 & 18.4 & - & 15.1 & 10.2 & 8.0 \\
\hline$G^{\prime}$ & 23.7 & 24.1 & - & 14.6 & 7.1 & 8. 3 \\
\hline $\mathrm{H}^{\prime}$ & 18.5 & 17.5 & - & 13.2 & 9. 9 & 9.7 \\
\hline $\mathrm{I}^{\prime}$ & 23.5 & 21.5 & - & 14.4 & 11.0 & 11.0 \\
\hline $\mathrm{J}^{\prime}$ & 20.6 & 21.0 & - & 13.5 & 7.3 & 7.9 \\
\hline Mean & 22.2 & 19.7 & - & 14.4 & 8.3 & 7.1 \\
\hline angle & $1.24^{\prime}$ & 1. $40^{\prime}$ & - & $1.79^{\prime}$ & 3. $32^{\prime}$ & $3.83^{\prime}$ \\
\hline
\end{tabular}

感を，采件性，無光沢な白っぼい 面と感じることがわかった。これ対 し織維束がランダムな綿朱子では, 両

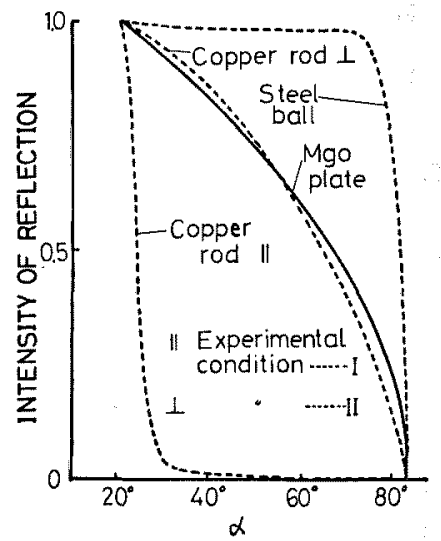

Copper rod : dia $8 \mathrm{~mm}$ Length $200 \mathrm{~mm}$ Contrast ratio of light and shade 5.5

Fig. 3. Reflecting distribution of steel ball and copper rod.

Table 5. Recognition of figure

\begin{tabular}{c|c|c|c|c}
\hline $\begin{array}{l}\text { Contrast } \\
\text { ratio of } \\
\text { light and } \\
\text { shade }\end{array}$ & \multicolumn{2}{|c|}{$\begin{array}{l}\text { Limit of recogni- } \\
\text { tion of shape }\end{array}$} & \multicolumn{2}{|c|}{$\begin{array}{l}\text { Limit of recogni- } \\
\text { tion of existance }\end{array}$} \\
\cline { 2 - 5 } Distance & $\begin{array}{c}\text { Visual } \\
\text { angle }\end{array}$ & Distance & $\begin{array}{c}\text { Visual } \\
\text { angle }\end{array}$ \\
\hline 1.2 & $8.21 \mathrm{~m}$ & $8.4^{\prime}$ & 19.47 & $3.5^{\prime}$ \\
1.5 & 11.96 & 5.8 & 27.52 & 2.5 \\
2.0 & 14.91 & 4.6 & 37.27 & 1.9 \\
4.0 & 16.67 & 4.1 & 45.85 & 1.5 \\
6.0 & 18.99 & 3.6 & 57.82 & 1.2 \\
\hline
\end{tabular}

性が高いのに対し，銅棒の条件への測定では正反射方向 にするどいピークを持つ分布となる。

以上の結果から，次のことが推定できる。テクスチャ 一の大きさが目の分解能（視角）以下となった場合に

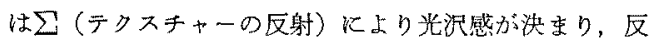
射光の分布が桩散光に近い面は無光沢面と憼じられ，平 板の反射光分布に近似していれば平板と注洼同質の光沢 感が感じられる。一方，テクスチャーの大きさが目の分 解能より大きい場合は、テクスチャ一のある面は，ちょ らど反射小素面をチリバメたような不連続なキラキラし た光沢感が感しら机るが，その反射小菜面の光沢感は平 板と質的に変化しない。

これらの結果を織物炕ついて確かめるため，絧，アセ テート，レーヨン，綿の各素子織物にアルミニウム蒸着 をほどこした試料を用い，銅棒を並べた面と同様の観測 条件下で観测させたが，䋧，アセテート，レーヨン素子 では，目の分解能 (視角) 以下の銅棒の観測結果と同様 に，すへての被験者が条件 I では，アルミニウムの光沢

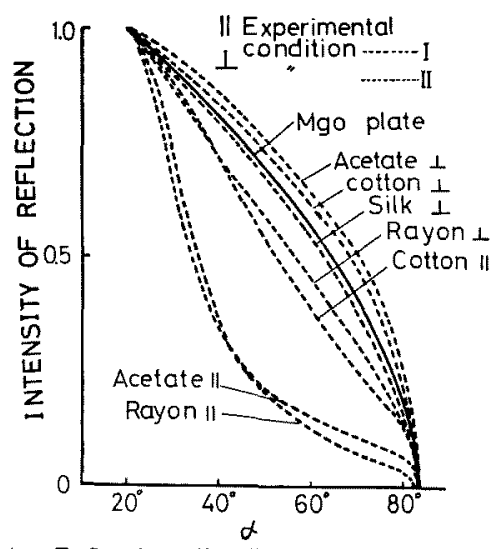

Fig. 4. Reflecting distribution of satain weave.

観測力向共汪とえど光沢感は感じられないとの結果を得 た。な怙，各試料の拡散区射曲線を第 4 図に示したが， 反射光分布は，銅棒の場合とよく近似して和り，先の推 定をよく裏づけている。

さて，以上の結果は，㧨散反射光付対し一つの規準を 与亲ている。すなわち，鋼球，銅棒，アルミ蒸着布いず れの場合も，その反射情面反射のみであり，いわゆる 正反射光が表面の形状により散乱しているもので，ミク 口な部分 (反射小素面) の反射は，すべて方向性を持っ ているにもかかからず，反射小素面の方向性がランがム に近いたる，面全体としての反射は，拡散光に類似して いるにすぎないといらことができる。しかるに，この面 を目で钼測する場合には，反射小素面の光っているもの 


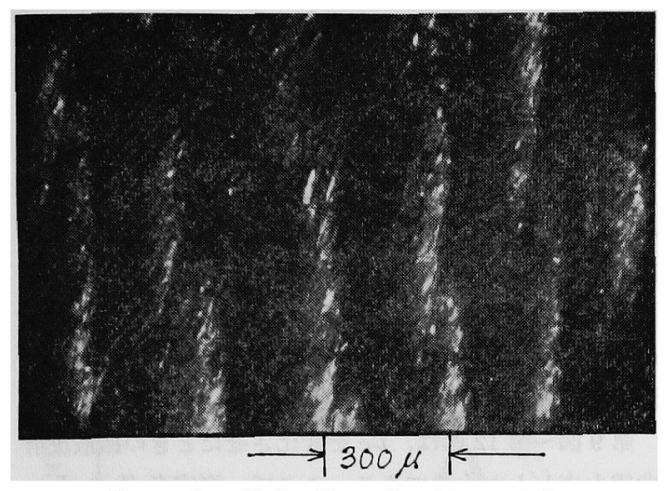

Photo. 1. Reflection of cotton satain.

の間隔が，目の分解能 (視角で $1^{\prime}$ ) 以下であれば，両者 の区別ができず，全体を積分した明るさの面と感じられ 拡散反射面と全く同様に感じられることになる。すなわ ち，拡散反射面とは，肉眼を規準にとった場合は，その 面の反射光が 3 次元的にあらゆる方向で輝度一定であ り，その反射小素面の大きさが目の分解能以下の間隔の 面と定義することができる。

写真 1 は, 綿糸子織の表面の顕微鏡写真であるが，こ こで, 繊維の光っている部分の大きさは, 断面方向（径 $20 \mu)$, 軸方向へも $100 \mu$ 以下であり, 目の分解能以下 であることは明らかである。したがって，綿朱子のよ5 に紡續采による織物では, 繊維束全体の区射光の分布の みにより光沢感が支配されることになる。

\section{2 瀻維の平行性と偏光反射特性}

さきの「単瀻維の反射についての扱い」出に特いて, フィラメント杀の朱子織のよ5に, 平行繊維束で織られ た，交錯点の少ない織物の偏光反射特性が，たて方向 （測定条件 I）上こ方向（測定条件II）で著しく異なる のは, 織維内部からの反射光が，上こ方向の测定条件で は 2 次元的な方向変化をするため, 偏光の性質変化がな いのに対し，たて方向では，3次元的な方向変化を受け るため, 偏光が性質変化することによるものと推定し た。

第 5 図〜第 8 図は, 測定条件 I, IIで $\alpha$ を变化させた ときの，反射光の強度分布を示したもので， $L_{\mathrm{ss}}, L_{\mathrm{ps}}$ な どは，入射する偏光，受光する偏光を変えたときの反射 の強さを示し， $\mathrm{p}, \mathrm{s}$ の添字は偏光の種類を表わしてい る。 $[\mathrm{p}(\mathrm{s})$ 偏光 : 入射面と偏光面が平行(垂直)な平面偏 光]

四から明らかなように, 瀻維が平行な, 絹朱子,では たて，よこ方向の偏光反射強度が著しく異なっているの に対し，紡績系である綿朱子では，両者の違いがほとん どないことがわかる。第 6 図は, 綟の同一試料を蒸留水
に浸せきした状態での測定結果を示したが濡れた状態で は, 反射光の強さは，一様に減少し同時に偏光反射特性 が測定条件によってあまり变らなくなることがわかる。

乾いた状態での反射と，濡らした状態での反射の違い は, 布内部の空気一繊維境界面が; 水一緎維の境界面に 置き変ったことにより屈折率の差が減少し反射光が減少 することによるものと考光られる。実験結果は，上述の 推定をよく裏つけているものといえる。

2.3 バルキー糸を使ったときの緎維の平行性と

反射特性との関係の測定

次に纎維束がランダムな方向性を持つ場合には，その 光っている部分の大きさ，反射光の分布なぞから考光，

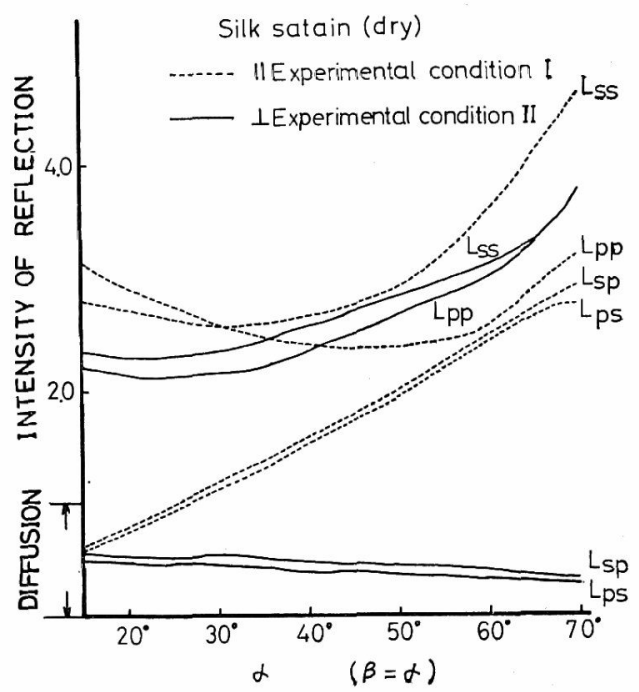

Fig. 5. Reflecting properties of fabric.

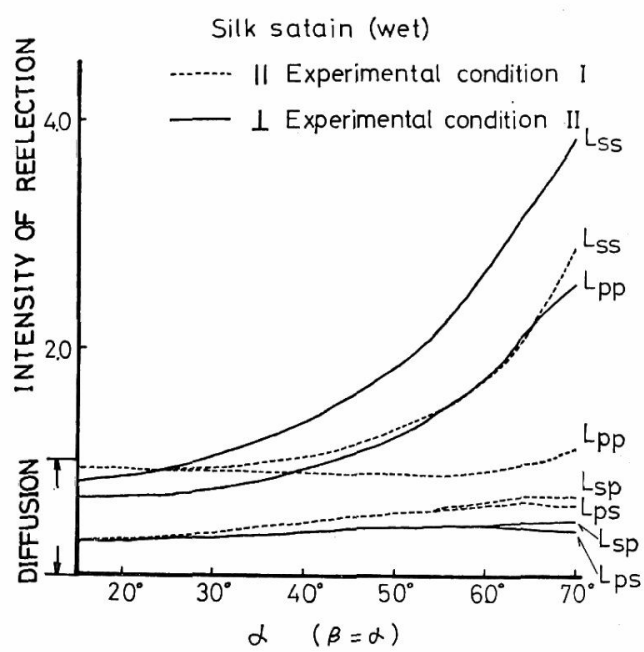

Fig. 6. Reflecting properties of fabric. 


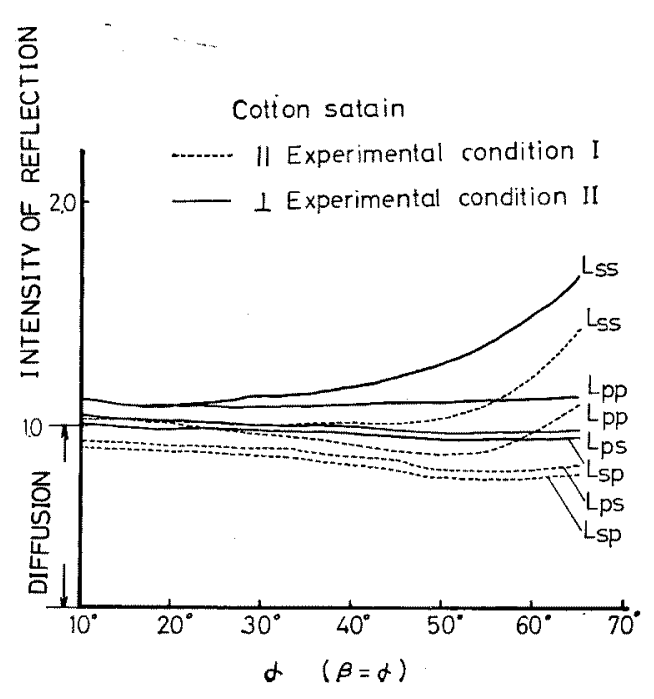

Fig.7. Reflecting properties of fabric.

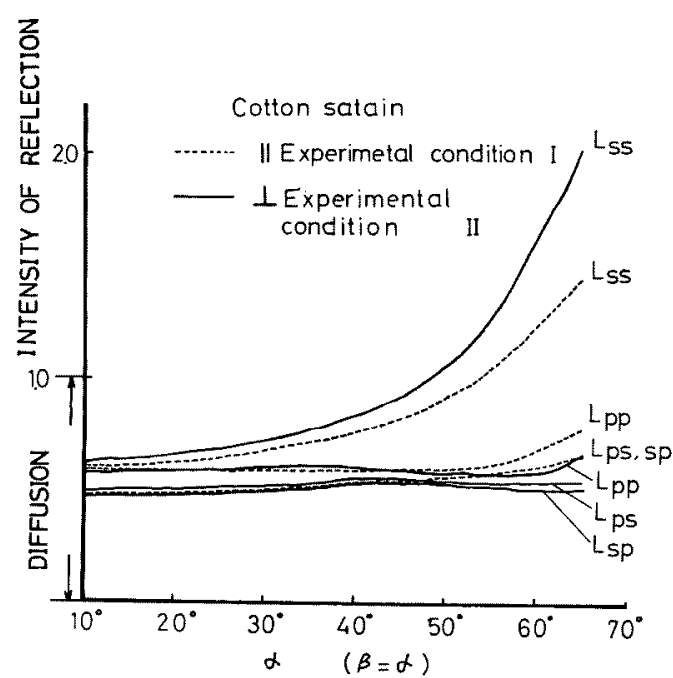

Fig. 8. Reflecting properties of fabric.

抎散板と同様な光沢感となることが推定できるが, 繊維 束の平行性が失なわれていく過程とその光沢感が失なわ れる過程との詨応について，バルキ一系を使って検討し to

ナイロン6，バルキー系を，クリンブを伸ばした状態 で平行に引きそろ克た試料を用い，その試料長を变化さ せることにより種々のクリンプ状態を作り，その反射光 分布，痛光特性の澌定を行なった。また，X線回折像を とり，クリンプ状態と回折スポットの黑化度との関係を 調べた。

さて，綨維の配列度の㲘定は，多くの研究者により行
なるれているが, Morton, 井谷らは，繊維の配列度を次 のように定義している。「スライバの一定区間炕如いて， その軸方向への織維の平均射影長と平均瀻維長の比でス

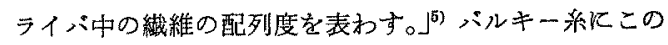
定義を適用すれば，クリンプを引伸ばした状態の試 長 $L_{0}$ とクリンプを与をた状態の試長 $L_{C}$ との比 $L_{C} / L_{0}$ が 㵶維の配列度表わしていることになる。そして完全平 行㵶維束では 1 となり,ランダムの場合は $(2 / \pi r) \int_{0}^{\pi / 2} r \sin$ $\theta d \theta=0.637$ となり，その他の配列度のときは，攵の中 間値をとることになる。

第 9 図一第 12 図は， $L_{C}$ 变化させたとさ拡散反射 曲線を表わしたるのである。ここで, 測定条件の $L_{\mathrm{p} \text { s }}$, $L_{\mathrm{sp}}$ 成分についてみると, 㵶維が完全平行な場合にはこ れらの成分は，㵶維のにごりなどによる拡散成分で，緎 維の境界面の反射とは㷛関係ないわゆる昖散反射成分で あると考劣られる。また，繊維がランダムな状態での反 射は拡散反射に近いるのといえることについては先議 論したが，緎雅がランダム状態での $L_{\mathrm{sp}}, L_{\mathrm{sp}}, L_{\mathrm{pp}}, L_{\mathrm{sp}}$ の各成分は測定条件 I II共に拉散板の反射光分布とよく 類似していることからすいえよう。

さて，湘定条件而の $L_{\mathrm{spp}}, L_{\mathrm{ps}}$ 成分怔，すべての平行 状態で類似の分布を示し，共の上限がランダム状熊の分 布であり，下限が平行状態の分布であることから，測定 条件 I $L_{\mathrm{Bp}}, L_{\mathrm{p} E}$ 成分は, 緎維の平行性に関係なく搪

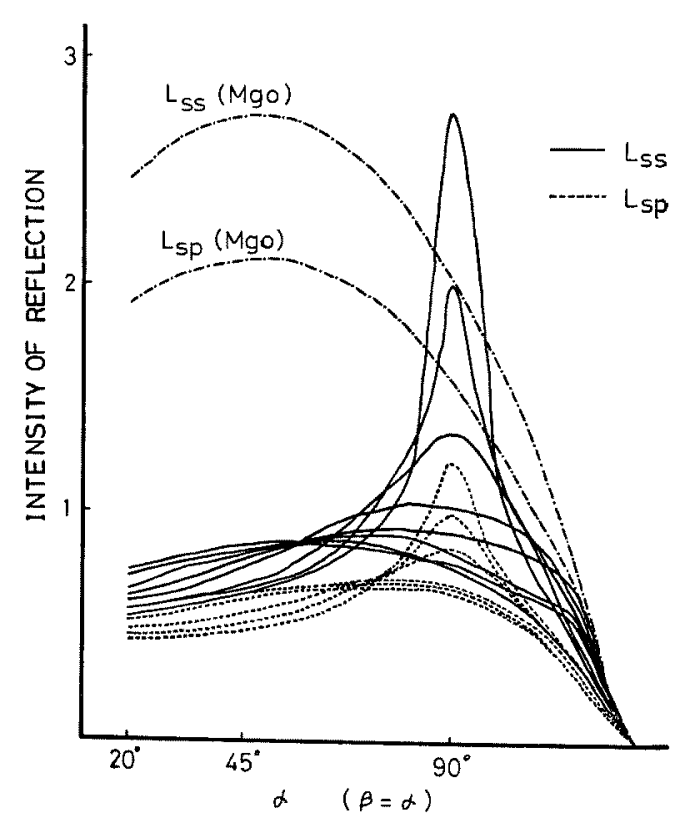

Fig. 9. Reflecting distribution of fiber bundle, Experimental condition I. 


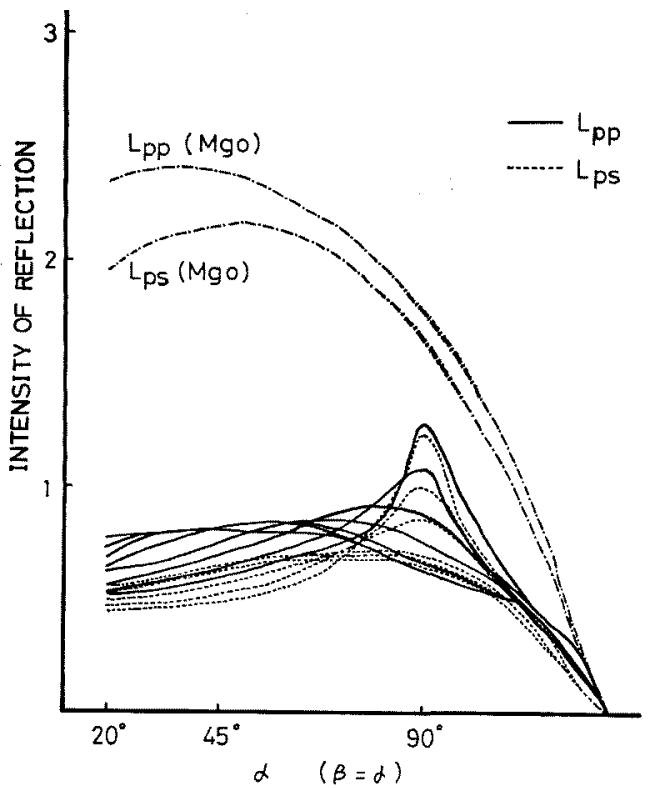

Fig. 10. Reflecting distribution of fiber bundle, Experimental condition I.

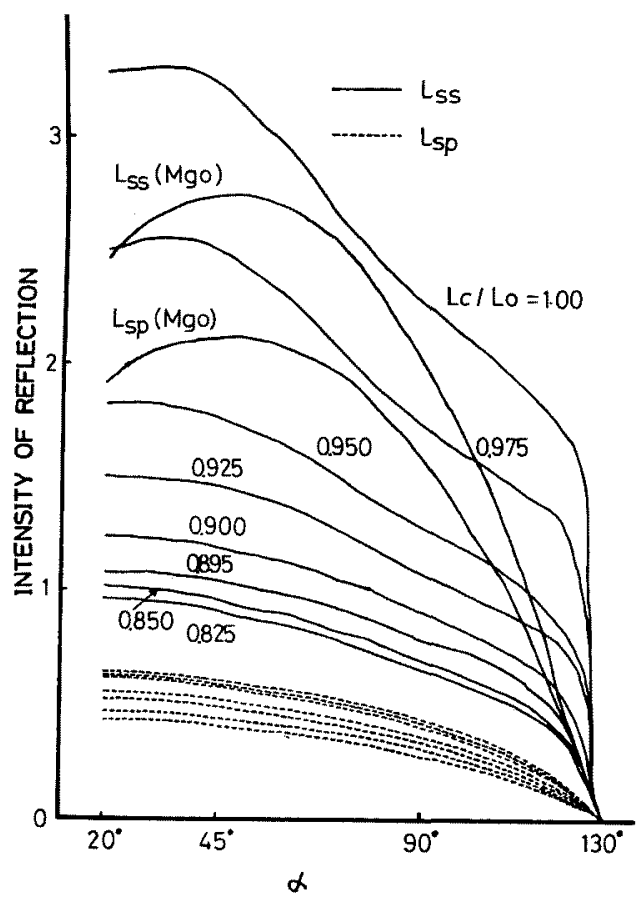

Fig. 11. Reflecting distribution of fiber bundle, Experimental condition II.

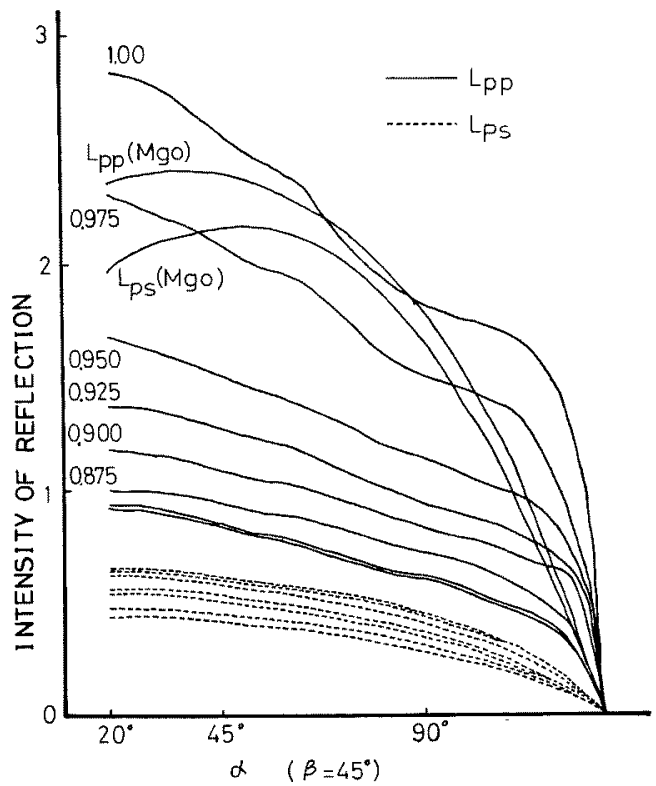

Fig. 12. Reflecting distribution of fiber bundle, Experimental condition II.

散成分であると考竞ることができる。な牧，この問題 は，後の反射成分の分離の項で再検討する。

さて, 反射光分布, 偏光性, X線回折スポットの黑化 度のそれぞれの測定から，㵶維の平行性を表わすパラメ ーターとして次の量を選んだ。

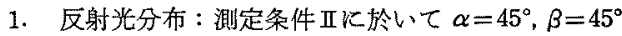
の反射光束と $\alpha=45^{\circ}, \beta=0^{\circ}$ の反射光束との比（いわ ゆる対比光沢度 $\left.\left(45^{\circ}\right)\right) C_{R}$

2. 偏光性：湘定条件で $\alpha=45^{\circ}, \beta=45^{\circ}$ のときの $L_{\mathrm{sg}}$ 成分と $L_{\mathrm{sp}}$ との比で表わす。 $P_{R}$

3. X線， $\mathrm{X}$ 線回折の回折スポットの黑化度を，末照 射フィルムの透光量と回折スポットの透光量との比によ り表わす。（な拈，利用した回折スポットは，赤道線上 の最強のものである。 $B_{R}$

そして，Morton らの瀻維の配列度との関係を表わし たのが 13 図である。図から，それそれれの゚ラメータ は，よい対応関係にあり，配列度に対し双曲線型の関係 を示している。

次に，クリンプ曲線を正弦曲線と仮定したときの繊維 の平行性について考壳てみる。

纎維束は，位相のランダムな周期曲線とみなすことが でき，繊維束の十分大きな部分をとれば，種々の方向を 向いた擮維の集合と考えることができる。このうち軸方 向を向く部分の全体に対する割合は，クリンプ曲線の一 


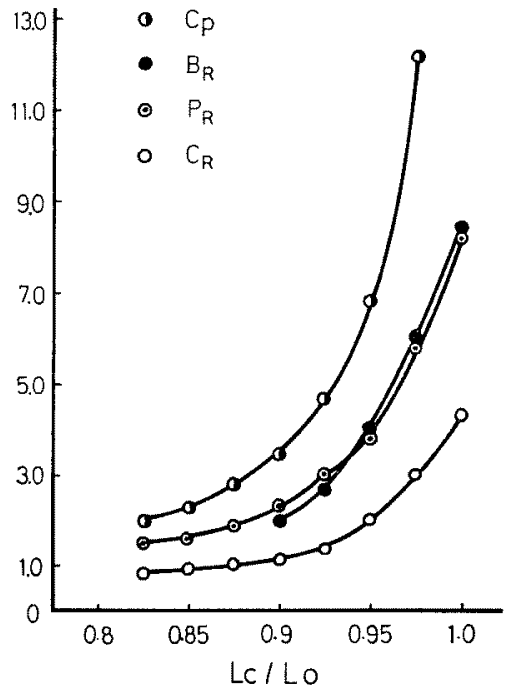

Fig. 13. Relation between three parameters and parallel property of fiber bundle.

周期に相当する長さのうち，軸に平行とみなせる部分の 長さの占める割合に等しいと考えられる。したがってク リンプ曲線を正弦曲線と仮定すれば

$$
L_{C} / L_{0}=\left(\frac{\pi}{2}\right) / \int_{0}^{\pi / 2} \sqrt{1+a^{2} \cos x} d x
$$

となり，鐡維軸汇平行とみなせる部分と $\theta_{0} \geqq \tan ^{-1} \frac{d}{d x}$ $(a \sin x)$ とすれば，クリンプ瀻維の平行性は $L_{C} / L_{0}$ の 関数として計算できる。第 13 図のは $\theta_{0}=1^{\circ}$ として算 出した結果を、 ランダム状態 1 をとして $L_{C} / L_{0}$ に対しプ ロットしたるのである。この結果は，先の3つのパラメ 一夕と同様， $L_{C} / L_{0}$ に詨し双曲線型の関係を示して括 ク，先の3つのパラメータはむしろここに示した平行 性近いものを表わしているといえる。

さて，パラメータ中，対比光沢度は，系の場合には， 視覚光沢度と良い相関性を示すことは，Fourt らにより すでに報告されておりの゙，この実験でも $L_{C}$ の增加にし たがい光沢感の急激な增加が見られた。

\section{3 反射成分の分離法と緎維の平行性}

絨維束の内部境界面からの反射，表面加らの反射，緎 維内部の拡散粒子に上る反射の3つの反射成分を分離与 るには，透明体の境界面の反射がフレネルの式で与占ら れ，内部の吸光粒子(染料など) の影響を受けないとの 仮定に立てば，次の力法により容易に行ならことか゚でき る。

1. 瀻維束名黑く染めて，内部へ透過する成分を吸收 させ，表面反射のみを分離する。

2. 緎維束を, 瀻維と同一屈折率の液体に浸せきし内
部境界面の反射を除き，表面反射，拡散粒子による反射 を取り出す。（この際，表面反射成分中には，瀻維表面 の反射以外飞, 繊維間に浸透した液体の表面反射它含 れる。そのため，繊維束の表面反射成分上り大さな表面 反射が表われるが，入射光に偏光を使用すれば，表面反 射成分は，入射偏光之同種の扁光になるのに効し，抎散

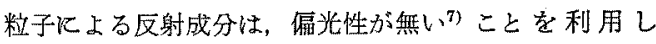
て，拉散反射成分と表面反射成分を分離できる。)

したがって，全体の反射光から表面反射，拡散反射を 差引いて内部境界面の反射を分離できる。

この分離法は, 繊維の平行性なと, 織物の構成条件と は無関係にできるが，这沉構成条件により反射光の性貿 変化が起る場合には，㐋の変化を考慮できないという問 題が残る。

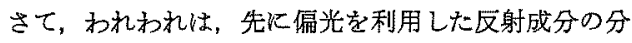
離を試みたが1，これは，平行纎維束の偏光反射特性の 違いを基にしたすのであった。

すなわち，平行䋐維束の反射を測定条件IIで測定した とき入射光火 $\mathrm{p}, \mathrm{s}$ 偏光孝用小，その反射光から $\mathrm{p}, \mathrm{s}$ 成 分のみを受光したときの反射成分は，次のように表わさ れる。( $M$ : 正反射光， $D$ : 桩散光)

$$
\begin{array}{ll}
L_{\mathrm{ss}}=M_{\mathrm{ss}}+T_{\mathrm{sg}}+D_{\mathrm{ss}} & L_{\mathrm{sp}}=D_{\mathrm{sp}} \\
L_{\mathrm{pp}}=M_{\mathrm{pp}}+T_{\mathrm{pp}}+D_{\mathrm{pp}} & L_{\mathrm{ps}}=D_{\mathrm{ps}}
\end{array}
$$

また，㵋定条件 Iでは

$$
\begin{array}{ll}
L_{\mathrm{s} s}=M_{\mathrm{ss}}+I_{R_{\mathrm{ss}}}+D_{\mathrm{ss}} & L_{\mathrm{sp}}=I_{R_{\mathrm{sp}}}+D_{\mathrm{sp}} \\
L_{\mathrm{pp}}=M_{\mathrm{pp}}+I_{R_{\mathrm{pp}}}+D_{\mathrm{pp}} & L_{\mathrm{ps}}=I_{R \mathrm{ps}}+D_{\mathrm{ps}}
\end{array}
$$

ここで， $T, I_{R}$ 成分については，Tを透過成分， $I_{R}$ を内部全反射成分としているが，T成分， $I_{R}$ 成分とも， 内部境界面での反射成分が忹とんどであり，T成分は， 縅維が軸方向に平行に引きそるえられている場合，軸に 垂直方向加ら p，s偏光を入射したとき汇は，瀻維境界面 の反射は，䛿光面が变化しないため，偏光性のみが $I_{R}$ と翼なることは，上述の検討から明らかである。なお，

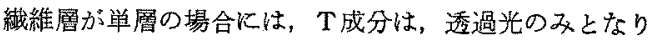
$I_{R}$ 成分は，内部境界面での反射となり，また，緎維が 異形断面の場合には， $I_{R}$ 成分の一部は内部境界面での 全反射光になることは単絨維の反射の議論から明らかで 放。

さて，㵶維束の平行性がくずれた場合には，測定条件 IKT成分が，測定条件Iにも $I_{R}$ 成分が入り込さこと になるが，紻維の平行性がくずれることにより拡散光の 定義そのものも変り，末た，䌖維束の反射光の拡散性之 偪光性とはよく対応していることについては，すでに議 論した。ここでは，測定条件II の湘定に入り込む $I_{R}$ 成 分注目し分離法の修正を試みた。

測定条件 II では 
Table 6. Isolation of reflecting element

\begin{tabular}{|c|c|c|c|c|c|c|c|c|c|c|}
\hline \multirow[b]{2}{*}{ Sample } & \multicolumn{3}{|c|}{ Reflecting coeficient } & \multirow[b]{2}{*}{$\left|\begin{array}{rr}L_{\mathrm{sp} 0} \text { of fabric } \\
L_{\mathrm{sp} 0} \text { of } & M_{j 0} \\
\times 100\end{array}\right|$} & \multicolumn{2}{|c|}{$\begin{array}{l}\text { Immersed met- } \\
\text { hod in liquid }\end{array}$} & \multicolumn{2}{|c|}{$\begin{array}{l}\text { Polarized light } \\
\text { method }\end{array}$} & \multirow{2}{*}{$\begin{array}{l}\begin{array}{l}\text { Yarn } \\
\text { density }\end{array} \\
\text { Warp } \\
\text { weft }\end{array}$} & \multirow{2}{*}{$\begin{array}{l}\begin{array}{l}\text { Yarn } \\
\text { denier }\end{array} \\
\text { Warp } \\
\text { weft }\end{array}$} \\
\hline & $\begin{array}{l}\text { Original } \\
\text { sample }\end{array}$ & $\begin{array}{l}\text { Immersed } \\
\text { in anisole }\end{array}$ & $\begin{array}{l}\text { Black } \\
\text { dyed } \\
\text { sample }\end{array}$ & & $M+I_{R}$ & $D$ & $M+I_{R^{\prime}}$ & $D^{\prime}$ & & \\
\hline Cotton satain & 75.5 & 38.5 & 2.5 & 72.0 & 39.5 & 36.5 & 3.5 & 72.0 & $\begin{array}{l}81 \\
27\end{array}$ & $\begin{array}{l}20 \mathrm{~S} \\
50 \mathrm{~S}\end{array}$ \\
\hline Silk satain & 67.5 & 14.0 & 2.5 & 38.0 & 56.0 & 11.5 & 29.5 & 38.0 & $\begin{array}{r}116 \\
42\end{array}$ & $\begin{array}{l}35 \mathrm{D} \\
35 \mathrm{D}\end{array}$ \\
\hline Rayon satain & 66.5 & 11.0 & 3.0 & 30.0 & 58.5 & 8.0 & 36.5 & 30.0 & $\begin{array}{r}110 \\
30\end{array}$ & $\begin{array}{r}70 \mathrm{D} \\
120 \mathrm{D}\end{array}$ \\
\hline Acetate satain & 51.5 & 11.0 & 2.5 & 17.0 & 43.0 & 8.5 & 34.5 & 17.0 & $\begin{array}{l}81 \\
36\end{array}$ & $\begin{array}{l}55 \mathrm{D} \\
55 \mathrm{D}\end{array}$ \\
\hline Acetate satain & 65.5 & 25.0 & 3.0 & 28.0 & 43.5 & 22.0 & 37.5 & 28.0 & $\begin{array}{r}125 \\
34\end{array}$ & $\begin{array}{r}50 \mathrm{D} \\
100 \mathrm{D}\end{array}$ \\
\hline Rayon satain & 59.0 & 11.0 & 3.0 & 30.0 & 51.0 & 8.0 & 29.0 & 30.0 & $\begin{array}{r}160 \\
43\end{array}$ & $\begin{array}{l}40 \mathrm{D} \\
75 \mathrm{D}\end{array}$ \\
\hline PET satain & 40.0 & 12.5 & 3.0 & 13.0 & 30.5 & 9.5 & 27.0 & 13.0 & $\begin{array}{r}114 \\
42\end{array}$ & $\begin{array}{l}30 \mathrm{D} \\
50 \mathrm{D}\end{array}$ \\
\hline
\end{tabular}

$$
L_{\mathrm{ss}}=M_{\mathrm{ss}}+T_{\mathrm{ss}}+D_{\mathrm{ss}}+I_{R \mathrm{ss}} \quad L_{\mathrm{sp}}=D_{\mathrm{sp}}+I_{R_{\mathrm{sp}}}
$$$$
L_{\mathrm{pp}}=M_{\mathrm{pp}}+T_{\mathrm{pp}}+D_{\mathrm{pp}}+I_{R_{\mathrm{pp}}} \quad L_{\mathrm{ps}}=D_{\mathrm{ps}}+I_{R \mathrm{ps}}
$$

そなるが， $L_{\mathrm{ps}}, L_{\mathrm{sp}}$ 成分は, 前述の上万に織維の平行性 のいかんにかか放らず拡散成分であると考克られる，す

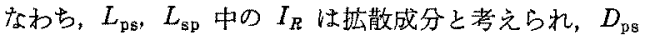
$+I_{R \mathrm{ps}}=D^{\prime}$ として新しく拡散光を定義する。これによ り，織物面からの反射光を方向性のある反射光と方向性 のない反射光という型で分離することができる。

$2 つ の$ 分離法についてみたとき，光沢感の評価が目を 規準记したものであることから，光沢感の表示といら観 点から，は後者の方法がより実際的であると思われる。

\section{3. 織物の光沢（質感）の表示}

前報では2)，テクスチャ一のある織物面の光沢表示に 対しても，平板状物体の光沢感（質感）表示々同一來標 示をあてはめて考光た。そしてその祭，テクスチャーに 上り光沢感がどのような影響を受けるか，また，積分球 法て測定した反射光中の方向性のある反射成分々方向性 のない应散成分とをとのような方法で分離するかなどの 点についての議論はさけ，結果のみる述べたが，上述の 結果を基に寸机ば，反射光の分離が，マクロなゴニオメ 一タにより可能な朱子織（たて。よこ糸の交錯が少なく 一方向の系のみ表面汇浮いている織物）では，前報で述 べた表示が可能であると考党る。第 6 表は，浸せき液に アニソール屈折率 1.52 用いて反射光分離した結果, 偏光を使った方法による分離結果を，また第 14 図，第 15 因灶々の測定例を示した。

一方，たて，よこ終 1 対 1 交錯する平織では，液体 浸せきの方法怢子織と同様に分蜼が可能であるが，偏
光による方法では，測定条件がたてよこ糸で異なってし まうため、テクスチャーのーつーつ耴つてて測定が必 要になる。

布面のマク口な反射特性と、テクスチャーのミクロな 反射特性との関保掠よび，平織物へのこの表示法の適用 については別に検討する予定である。

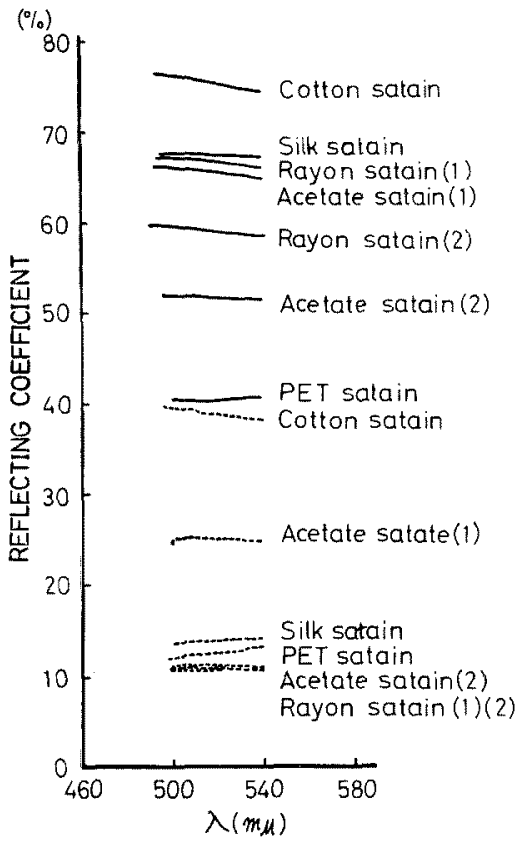

Fig. 14. Reflecting coefficient. 


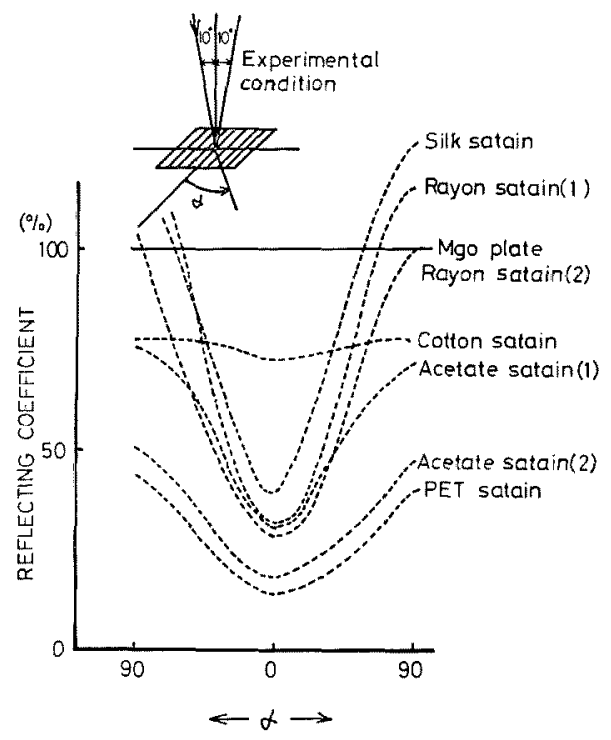

Fig. 15. Reflecting properties of fabric.

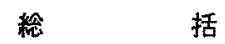

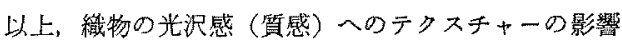
を中心議論したが，その結果次のよ5なことがかか。 to

1. 物体面にテクスチャ一が存在し，反射光が散乱す
る場合でも，テクスチャーが目の分解能より大きいとき には，その光沢感は平面状態の光沢感と質的に変化しな い一方，テクスチャーの大きさが目の分解能上り小さ くなった場合には，その光沢感は之（テクスチャ一の反 射光分布）により決定される。これは目が物体面を映像 としてとら党ているためと考えらるる。

2. 織物の場合, 纎維の平行性が光沢感に大さな影響 を及ぼしているが，これは，㵶維形態に関俰する反射成 分（蟣維一空気の境界面での反射）の方向性が瀻維の平 行性により变化するためと考劣られる。

3. 織物の光沢感と織物面からテクスチャーを除いた

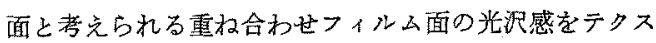
チャ一の大きさと目の分解能という面から関係つけるこ とができたを思ら。

終りに，本研究にあたり種々ご教示戴だきるした東宗 太学鳥居助教授ならびに緎維高分子材料研究所須田紀子 技官に深謝致します。な蛒，本研究の一部性，1970 年 繊維高分子材料研究所研究発表会に叔いて発表した。

\section{文献}

1）稲垣，赤川；緎工試報告，No. $72 ， 79$ (1965)

2）稲垣，赤川 ; 䋐学諘, 27

3）横瀨；“視覚の心理学”, 共立出版（1968）

3）稻垣, 赤川1；緘学誌，25，207（1969）

5）例えば，井谷；機誌，9，461（1956）

6) L. Fourt, Textile Res. J., 24, 61 (1954)

7)田中；応用物理，26，85（1957） 